This is the peer reviewed version of the following article: Ferguson Andrew et al. 2011, 'Your Governance or Mine?', Wiley-Blackwell Publishing Asia, vol. 21, no. 4, pp. 406-417.. which has been published in final form at http://dx.doi.org/10.1111/j.1835-2561.2011.00147.x This article may be used for non-commercial purposes in accordance With Wiley Terms and Conditions for self-archiving' 


\title{
Your Governance or Mine?
}

\author{
Andrew Ferguson*, Matthew Grosse, Stephen Kean and Tom Scott \\ University of Technology, Sydney
}

\begin{abstract}
In response to criticism directed at the resource sector's corporate governance, this paper examines the corporate governance and underlying firm characteristics of resource development stage entities relative to a size matched sample of non-resource firms. We find that resource DSE's have different governance characteristics in the measures of board independence, CEO-chair duality and CEO cash bonuses. Furthermore, there are differences in the information environment measures of analyst following, debt levels, stock market return and stock turnover. Considering we document substantial differences in underlying firm characteristics, corporate governance differences are likely appropriate to the mining industry and should not be uniformly labelled as 'bad'. Our results suggest that media rankings based on corporate governance scores may not accurately portray the resource sector. Overall, our results are of interest to Australian investors and regulators and contribute to a broader understanding of contextually contingent corporate governance.
\end{abstract}

Keywords: Corporate governance; resource sector

*Corresponding author: Andrew Ferguson, Discipline of Accounting, UTS, P.O. Box 123

Broadway NSW 2007, Australia.

Phone: +61 295143565

Fax: +61 295143669

Email address: Andrew.Ferguson@uts.edu.au 


\section{Introduction}

In a series of industry reports, the resource sector has been rated as having the worst corporate governance of any sector (WHK Horwath, 2009). The financial and popular media have cited these reports in drawing attention to the issue: 'Small shareholders are being warned to read the fine print before they invest in small mining companies. ${ }^{1}$ However, is singling out the resource industry for criticism on corporate governance valid? This paper empirically investigates whether Development-Stage Entities (DSE's) in the Australian resource sector have systematic differences in corporate governance compared to similar sized firms in other sectors. Following recent research, we argue that systemic differences in corporate governance are likely explained by the economic characteristics of resource DSE's and suggest that the label of 'bad' governance may not be appropriate (Armstrong et al., 2010; Brickley \& Zimmerman, 2010). ${ }^{2}$ This result contributes to the wider corporate governance literature and is of interest to Australian investors and regulators given the importance of the junior resource sector to the Australian equity market in terms of aggregate constituent numbers.

Superior corporate governance is argued to be associated with better firm performance (for example, Bhagat \& Bolton, 2008; Dahya et al., 2008), a lower cost of capital (for example, Anderson et al., 2004; Huang et al., 2009) and lower seasoned equity offering underperformance (Brown et al., 2009). Regulators also emphasise 'good' corporate governance, with the ASX issuing best practise guidelines. The financial press also increasingly covers corporate governance, frequently naming the resource sector as the 'worst

\footnotetext{
${ }^{1}$ Glanville, B. 2007, 'Corporate governance being forgotten: report', ABC News, 30 November 2007, available at www.abc.net.au/news/stories/2007/11/30/2105730.htm last accessed 5 June 2011.

${ }_{2}^{2}$ This study relies on the theoretical framework of previous corporate governance literature. It is not the objective of this paper to posit any alterative framework or empirical model for explaining corporate governance per se or to examine the performance ramifications of corporate governance systems in different contexts.
} 
offender' based on corporate governance scores. ${ }^{3}$ The WHK Horwath Rating System awards firms up to five stars based on ASX Corporate Governance Council Principles. However, this methodology implicitly assumes that more corporate governance or greater compliance is 'better' and rewards firms who 'box-tick', regardless of firm specific or other institutional and economic factors. This contrasts with a growing body of academic literature that criticises a 'one size fits all' or 'more is better' approach to assessing governance quality. Reviewing the literature, Armstrong et al. (2010) highlight the commonly held myth that it is easy to distinguish 'good' from 'bad' for any given corporate governance mechanism. This myth ignores economic arguments and empirical evidence on why firms that are labelled as having bad governance may have, for example, appropriately selected a board with low independence consistent with the firm specific situation. Brickley \& Zimmerman (2010) highlight how this myth has extended into two further myths; (a) the myth that it is possible to compute corporate governance scores and (b) the myth that it is possible to identify corporate governance 'best practice.'

Providing empirical evidence that one size does not fit all, Coles et al. (2008) find that research and development $(\mathrm{R} \& \mathrm{D})$ intensive firms have larger boards and a higher proportion of executive directors. They interpret this finding as consistent with the board's increased demand for inside technical knowledge in order to properly advise and monitor management. Matolcsy \& Wright (2007) document that equity-based compensation, an American hallmark of 'good' corporate governance, is far less common amongst Australian firms. They interpret this finding as consistent with the inappropriateness of such compensation schemes for comparatively smaller sized Australian firms. Patro et al. (2009) examine 82 firms over 65 years and document that changes in firm size, growth opportunities, merger activity and

\footnotetext{
${ }^{3}$ WHK Horwath '2009 Corporate Governance Report: Companies ', p. 3.
} 
geographical expansion are associated with changes in board characteristics. This suggests a wide range of factors affect governance and that a simple 'good' or 'bad' label is misleading. Linden \& Matolcsy (2004) find a positive association between WHK Horwath governance ratings and firm size in the largest 250 Australian firms in 2001, illustrating the strong effect of firm size on compliance. In summary, compliance with corporate governance mechanisms is costly and firms must balance the costs and benefits of specific mechanisms within their overall governance package (Armstrong et al., 2010).

Therefore, we argue that the underlying firm characteristics of resource DSE's help explain rational corporate governance choice, rather than a simple 'good' or 'bad' dichotomy. As with R\&D-intensive firms, resource DSE's are a firm type where corporate governance mechanisms that may be classified as 'bad' governance can be economically justified. The organisational characteristics of a typical resource DSE are summarised in a recent observation by Tony Featherstone:

\begin{abstract}
'Boards of micro-cap explorers often seem out of step with modern governance practices. It is not uncommon for a board of a newly listed explorer to have an executive chairman, managing director and only one independent director. $^{, 4}$
\end{abstract}

The question we consider is whether the corporate governance of resource DSE's is different from similar sized non-resource firms. Rather than singling out resource explorers from the micro-cap end of the market for criticism, we investigate whether the corporate governance

\footnotetext{
${ }^{4}$ Featherstone, T. 2010, 'A new gold rush', Company Director Magazine, September.
} 
differences that do exist between sized matched resource DSE's and non-resource firms, are explained by underlying firm characteristics. This can be formally stated as:

H1: Differences between the corporate governance characteristics of resource and non-resource firms are a function of firm characteristics.

\section{Research Design}

\subsection{Sample selection}

Following Ferguson et al. (2011), a firm is designated as a resource DSE if its operating revenue is less than $5 \%$ of market capitalisation. A preliminary sample of 100 ASX-listed DSE's from the resource industries (GICS sectors 101020 and 151040, namely Oil, Gas and Consumable Fuels and Metals and Mining, respectively) is randomly selected for the year 2009. To provide a comparison, 100 non-resource firms are uniquely matched on the basis of market capitalisation at $31^{\text {st }}$ of December 2009. Three firms lacked a full 2009 annual report, six firms are transitioning between resource and non-resource industries, whilst two firms are under suspension from active trading on the ASX. These firms are replaced by a further eleven randomly selected firms for the corresponding sub-sample. This leaves a final sample of 100 resource DSE's and 100 size-matched non-resource firms. ${ }^{5}$ The year 2009 is chosen as it is a recent year with full availability of annual reports. This study is limited to one year of data (2009) to avoid the econometric issues involved with pooling multiple years of data when the underlying corporate governance variables are sticky. ${ }^{6}$ The stickiness of corporate

\footnotetext{
${ }^{5}$ We classified 652 ASX listed resource firms as a DSE in 2009. Due to the problematic nature of matching at the smaller end of the market, there are 347 unique firm-pair matches between resource DSE's and non-resource firms. Due to the lack of machine readable data, issues with delisting, market suspensions and no annual reports and the laborious nature of data collection, we limit ourselves to 200 observations.

${ }^{6}$ Future research may wish to consider whether the evidence (and inferences) in this paper are subject to variation across time. Corporate governance trends are influenced by regulatory trends (Tyler et al., 2010). However, the association between underlying firm characteristics and corporate governance is unlikely to vary significantly from year to year.
} 
governance mechanisms is emphasised by Brown et al. (2011), who document correlations of around 0.8 between adjacent years of firms Horwath corporate governance scores.

Due to the broad definition of corporate governance there is a large range of potential measures to examine, for example Larcker et al. (2007) investigate 39 measures. Corporate governance studies frequently attempt to condense various corporate governance mechanisms into an objective corporate governance 'score'. However, these scores may not facilitate a meaningful comparison between strategies, life-cycle stages and operating environments (Armstrong et al., 2010; Brickley \& Zimmerman, 2010). Therefore, we examine a limited range of corporate governance variables that are commonplace in the extant literature (Brown et al., 2011). They are not meant to be, nor could possibly be, an exhaustive list of all the possible mechanisms utilised by corporations; however they do provide a concise overview of popular governance measures.

The variables we examine are based around the components of the Horwath corporate governance rating methodology. ${ }^{7}$ First, we use measures of board size, board independence and CEO/board chair duality, which are also key ASX principles for good corporate governance. Measures of board subcommittee size and independence are not examined due to inapplicability and strong correlation to board size and independence when overall board size is small. Second, to allow quantitative analysis, we report chief executive officer (CEO) compensation, shareholding levels and shareholder concentration rather than the existence of related policies used in the Horwath corporate governance scores. Third, we substitute a measure of top-tier auditor for the ratio of non-audit fees to audit fees. We argue that interpreting the audit fee ratio is complicated for small firms considering the practical

\footnotetext{
${ }^{7}$ As outlined in the '2009 WHK Horwath Corporate Governance Report', p. 6-9.
} 
reliance on outsourcing accounting and consulting functions. Furthermore, top-tier auditor usage can potentially signal stronger external monitoring to the market (DeAngelo, 1981). To structure our discussion, variables are classified into four categories; ASX Principles for good governance, CEO compensation, ownership structure and audit. All corporate governance data is manually collected from annual reports and variables are defined in Table 1.

Insert Table 1 about here.

To allow the investigation of differences between the resource and non-resource firms, we report a range of underlying firm characteristics. They are classified into four categories; employees, financial position, financial performance and stock market activity. Stock market and analyst information are collected from DataStream and IBES databases, respectively. All other firm information comes from FinAnalysis and we manually collect missing data from annual reports. A full description of the underlying firm characteristic variables accompanies Table $1 .{ }^{8}$

\subsection{Research design}

To illustrate differences between resource and non-resource firms we report descriptive statistics on both corporate governance and firm characteristics. We compare whether the means of resource and non-resource firms for each variable are significantly different using Student $t$-tests. We also report whether the ranks of variables are significantly different using the Mann-Whitney $U$ test and report $z$-statistics. This parametric and non-parametric univariate analysis allows us to identify any trends or difference in the corporate governance and firm characteristics of resource and non-resource firms. However, a potential caveat of

\footnotetext{
${ }^{8}$ A potential methodological issue with doing research on small firms is poor database coverage. Furthermore, small firms can have legitimate observations that are well outside the expected norm due to changing conditions or firm structure.
} 
univariate tests is that they only illustrate significant differences, not causality or associated differences, leaving interpretation open.

To provide further insight on whether there is a difference between the corporate governance of resource and non-resource firms after controlling for underlying firm characteristics, we conduct several multivariate tests. We regress corporate governance measures (CorpGov) on a categorical variable equal to one if the firm is in the resource sector (Resource) and firm characteristics (FirmChar). A significant coefficient on Resource would suggest a difference in the corporate governance of the resources sector that is not explained by the firm characteristics included in the regression. Firm characteristics are excluded where there is potential multicollinearity or other econometric issues. ${ }^{9}$ We recognise that causal inferences, endogeneity and correlated omitted variable bias are particularly problematic in corporate governance research (for example, Armstrong et al., 2010; Brown et al., 2011). However, due to the exploratory nature of this paper and the number of multivariate tests conducted, thorough sensitivity testing and generalisability of specific results is a topic for future research. For continuous corporate governance variables the ordinary least squares (OLS) regression is specified as:

CorpGov $=\alpha+\beta_{1}$ Resource $_{i}+\beta_{2}$ FirmChar $_{i}+\varepsilon$

For categorical corporate governance variables the logistic regression is specified as:

$$
\operatorname{Logit}(\operatorname{CorpGov}=1)=\alpha+\beta_{1} \text { Resource }_{i}+\beta_{2} \text { FirmChar }_{i}+\varepsilon
$$

\footnotetext{
${ }^{9}$ For example, number of analyst and analyst coverage are highly correlated therefore we exclude number of analysts. Results are qualitatively similar to alternate financial characteristics inclusion and exclusion.
} 


\section{Results}

\subsection{Univariate analysis of corporate governance}

To identify any trends, we begin by comparing the means and medians of corporate governance variables between resource DSE's and non-resource firms in Panel A Table 2. First, in contrast to media reports, resource DSE's only have marginally smaller boards (means of 4.3 to 4.6 directors). Second, the board independence results (means of $43 \%$ and $45 \%$ for resource and non-resource sub-samples, respectively) potentially highlight the inapplicability of ASX recommendations and corporate governance scoring systems to small firms. Third, both sectors typically separate the roles of CEO and chairman, but resource DSE's have higher rates of chair/CEO duality than non-resource firms.

Mean cash pay for CEO's is similar, but the median cash pay for non-resource CEO's is almost $50 \%$ more $(z$-stat $=-3.018)$. We document that about half of both types of CEO's (resource and non-resource) have equity compensation plans, while Matolcsy \& Wright (2007) document that about two-thirds of ASX 500 firms have equity compensation in 19992001. This difference is likely a joint function of time and that our sample firms are significantly smaller. However, resource DSE CEO's have a far lower cash bonus frequency ( $8 \%$ to $42 \%$ ). Resource DSE's have nearly half the frequency of top-tier auditors as nonresource firms ( $28 \%$ to $46 \%)$.

Resource DSE's have lower mean ownership concentration than non-resource firms (less substantial shareholders and smaller largest and top 20 shareholdings). The governance ramifications of ownership structure are difficult to interpret. Large independent shareholders have a strong economic incentive to monitor management (Shleifer \& Vishny, 1997) and management shareholdings bond their interests' to shareholders (Jensen \& Meckling, 1976). 
However, particularly large shareholders can act against the interests of the minority shareholders (Morck et al., 1988; McConnell \& Servaes, 1990; Shleifer \& Vishny, 1997). Although ownership concentration does have an effect on corporate governance, it is not a specifically designed corporate governance mechanism and is influenced by other factors. Therefore, interpreting the determinants of ownership concentration through a corporate governance framework is highly problematic (Armstrong et al., 2010).

Resource firms also have significantly lower board (excluding CEO) and KMP shareholdings (excluding executive directors). This smaller shareholding could be due to the early life cycle stage of resource DSE's. The lower KMP shareholding is likely a mechanical function of the fewer KMP in resource DSE's as outlined below in Section 3.2, although it also suggests that organisational size is a key driver of total KMP shareholding. However, there are other potential explanations for these results. We do not report regression results for ownership concentration measures due to the lack of theoretical grounding, which makes interpretation of any significant determinants problematic.

\subsection{Univariate analysis of firm characteristics}

To inform our analysis on whether any observed corporate governance differences can be explained by underlying factors, we next discuss the firm characteristics of resource and nonresource firms as outlined in Panel B Table 2. First, resource DSE's have a significantly lower number of key management personnel (KMP) disclosed in annual reports, a smaller non-executive employee expense and a higher CEO pay to employee expense ratio (mean of $729 \%$ relative to $47 \%) .{ }^{10}$ These results support anecdotal evidence that resource DSE's have as few as one or two executive directors who are normally involved in project acquisition or

\footnotetext{
${ }^{10} 11$ Resource DSE's and 4 non-resource firms did not report a separate employee expense. For these firms the nearest equivalent (typically administrative expense) was used instead, results are robust to their exclusion.
} 
project generation activities such as designing drilling programs for existing projects. These executives are often accompanied on the board by non-executives who routinely hold significant industry experience and act in an advisory capacity. Resource DSE's may also employ a receptionist as the only other employee, with other tasks outsourced.

Second, resource DSE's have significantly less long term debt and leverage, with a mean debt-to-equity ratio of 0.011 for resource DSE' s relative to 0.277 for non-resource firms. Furthermore, resource DSE's have a higher proportion with negative free cash flows (93\% for resource, $57 \%$ for non-resource). ${ }^{11}$ Consistent with capital scarcity and cash conservation for mineral exploration, resource DSE's have higher current ratios, reflecting their need to raise cash to fund exploration, but similar rates of cash burn (amongst the firms with negative free cash flows). This result is similar to resource DSE descriptive evidence reported in Ferguson (2011) and suggests that debt-based monitoring is very rare and that resource exploration is high risk. As the non-resource firms are matched based on market capitalization, the significantly lower total assets of resource DSE's reflects the lack of debt financing. This is an intuitive result, as typically the only real assets on resource DSE balance sheets are cash and deferred acquisition and exploration expenditure (which is subject to impairment provisions under AASB 6). Resource DSE's also have substantially lower profitability. Therefore, as traditional profitability analysis cannot be performed on resource DSE's, non-GAAP drilling, resource and reserve disclosure likely takes the place of GAAP financial performance-related information (Ferguson \& Crocket, 2003).

Insert Table 2 about here.

\footnotetext{
${ }^{11}$ Of the 57 non-resource firms, 12 were DSE's (primarily from the pharmaceutical development industry), whilst a further 28 were loss-making firms and a further 6 were financially distressed (Altman, 1968).
} 
Third, our univariate results suggest that resource DSE's have higher stock volatility than non-resource firms consistent with Ball \& Brown (1980). Furthermore, over this constrained sample window, share returns for resource DSE's are higher than for non-resource firms. This is likely to be primarily a function of the commodity boom but may also be a partial reflection of a small number of distressed firms in the non-resource sample. Share turnover which can proxy for stock liquidity, is also higher for resource DSE's. ${ }^{12}$

Fourth, non-resource firms have twice the frequency of analyst following and almost twice the number of analysts (amongst the followed firms). This observation suggests that despite the potentially higher demand for analysts as information intermediaries and a possible monitoring mechanism, analysts are more reluctant to publicly follow resource DSE's. Although we do not empirically examine this difference, this equity analyst reluctance could be due to a lack of the technical skills (analysts typically have a finance-based education, not geological or engineering-based). ${ }^{13}$

Overall, on a descriptive level our results suggest that resource DSE's have fundamentally different firm characteristics than non-resource firms. Broadly speaking, they have less long term debt, more cash on hand, better market performance and lower analyst coverage.

\subsection{Multivariate analysis}

Results from OLS regressions of the continuous corporate governance variables are reported in Table 3, with both models reporting $F$-statistics significant at the $1 \%$ level and adjusted $R^{2}$

\footnotetext{
${ }^{12}$ Once again it is difficult to disentangle the cyclical effects of the commodity boom from the underlying share turnover. In this regard, future research may wish to consider a wider time frame to control for cyclical effects (Ball \& Brown, 1980). Future analysis may also wish to disentangle the effects of non-resource DSE's and financially distressed firms.

${ }^{13}$ However, caution needs to be exercised in interpreting this analyst result given the dominance of boutique analyst resource houses which can be excluded from the IBES measure employed here.
} 
above 40\%. Furthermore, the Variance Inflation Factor's for the OLS Models I and II reported in Table 3 are lower than 6.8, suggesting no problematic multicollinearity (Lardaro, 1993). Results from logistic regressions of the categorical corporate governance variables are reported in Table 4, with all models reporting Chi squares significant at the $1 \%$ level and Pseudo $R^{2}$ ranging from $20 \%$ in Model I (Majority Board Independence) to $47 \%$ in Model IV (CEO Cash Bonus).

\subsubsection{ASX Principles}

OLS regression results from Table 3 Model I provide further confidence that there is no significant difference between the board size of resource and non-resource firms after controlling for differences in firm characteristics. This is contrary to evidence of larger boards in sectors where highly technical idiosyncratic information might be in greater demand, but consistent with the lower operational diversity of resource DSE's, who, given cash constraints often focus on the development of a single project (Coles et al., 2008). Total assets and analyst coverage are positively associated with board size, suggesting a strong correlation between firm size or project development and board size. Alternatively, if governance is linked to performance, analysts would rationally choose to follow firms with 'better' governance practises. We interpret the positive coefficients on KMP and negative free cash flow as consistent with board representation of management and creditors.

Table 4 Model I presents a logistic regression for boards with independence over/under 50\%. The significant negative coefficient on Resource $(p=0.067)$, suggests that after controlling for firm characteristics, resource DSE's are less likely to have a majority of independent directors. This result departs from the lack of a significant univariate difference in the percentage of independent directors outlined in Table 2, but is consistent with the greater 
proportion of insider directorship documented in other sectors where highly technical knowledge and experience is likely to be in greater demand (Coles et al., 2008). We also document that lower return volatility and higher turnover are positively associated with board independence, suggesting that the market either enforces, or is attracted to more independent boards. The negative association between return on assets (ROA) and board independence is likely a joint function of the large number of loss making companies in our sample as discussed above in Section 3.2 and that poorly performing firms are more likely to increase board independence (Bhagat \& Black, 2002).

Insert Table 3 about here.

The difference in the duality of resource firms documented by the univariate results is supported by a positive Resource coefficient in respect to chair/CEO duality in Table 4 Model II. This could reflect the importance of technical knowledge in guiding board discussions (Brickley et al., 1999). However, we cannot conclude this with any certainty and there are other possible explanations such as more powerful or skilful CEO's bargaining for the chairman role (Hermalin \& Weisbach, 1998). Furthermore, long-term debt and return volatility are positively associated with chair/CEO duality. This could be due to the large number of firms in our resource sub-sample without debt financing. Alternatively, it could suggest benefits from concentrated control or long term relationships. The negative association between ROA and duality contrasts with literature that poorly performing firms are more likely to separate the role of CEO and chairman (Chen et al., 2008). The different result is likely due to the greater relevance of non-financial information as a performance measure in the resource sector (Ferguson et al., 2011). 
In summary, our results support our hypothesis by suggesting that resource DSE's have greater duality and a lower frequency of independent boards, consistent with other sectors where highly technical knowledge is of greater importance.

\subsubsection{CEO Compensation}

In contrast to the univariate results, Table 3 Model II finds that Resource is not significantly associated to CEO cash pay, suggesting that the difference is a function of firm characteristics. The regression results indicate that the CEO's of more complex, high performing and riskier firms receive higher pay. As discussed above in Section 3.2, resource DSE's have higher market returns, turnover and volatility, consistent with CEO pay being a factor of rationally risk adjusted compensation packages (Conyon et. al., 2011).

The logistic regression results in Table 4 Model III show that there is no significant difference in equity plan usage by resource DSE's and that equity plan usage is predominantly a function of firm characteristics that arguably represent size, risk and performance. As discussed above in Section 3.2, resource DSE's have higher stock return, turnover and volatility in 2009. This suggests that equity plan usage is appropriate for small resource DSE's, considering that stock market efficiency is a key requirement for equitybased incentives to be an effective bonding mechanism. ${ }^{14}$

In contrast, but consistent with univariate results, Resource is significantly negatively associated to CEO cash bonus in our logistic specification in Table 4 Model IV. The negative association between CEO cash bonus and negative free cash flow, suggests that discretionary cash compensation for CEO's is highly dependent on firm cash position. Therefore, lower

\footnotetext{
${ }^{14}$ We acknowledge the difficulty and importance in disentangling the effect of the commodity cycle on stock price performance from managerial influences when designing an effective equity-based compensation system.
} 
cash bonus use by resource DSE's is unsurprising given the significantly greater cash constraints outlined above in Section 3.2 and is consistent with a further quote from Featherstone who suggests:

'Speculative explorers usually do not have the funds - or the need-for large boards with diverse skills. Nor do they have the cash for high director fees or executive salaries. $^{, 15}$

The positive association between analyst coverage and all aspects of CEO compensation could suggest that analysts are more likely to cover firms with 'star' CEO's or that analyst coverage is a proxy for future cash flow expectations or size effects. Overall, our results support our hypothesis by suggesting that resource DSE's only have different CEO compensation in terms of cash bonus use, which is consistent with the greater cash constraints faced by resource DSE's.

Insert Table 4 about here.

\subsubsection{Audit}

After controlling for firm characteristics, the logistic regression results in Table 4 Model V show that Resource is not significantly associated with lower top-tier auditor use. This contrasts with the univariate result in Table 2 and the significantly positive association between top-tier auditor use and employee expense, total assets and analyst coverage suggests that operational size or complexity is a key determinant of auditor choice. Furthermore, lower top-tier auditor use by firms with less total assets, but similar market

\footnotetext{
${ }^{15}$ Featherstone, T. 2010, 'A new gold rush', Company Director Magazine, September.
} 
capitalization, is consistent with a lower demand for premium audit services amongst firms with a higher proportion of off-balance sheet (unaudited) assets (Anderson et. al., 1993). Additionally, the greater value of non-GAAP drilling, resource and reserve disclosure for the resources sector (Ferguson et al., 2011), reduces the value of expensive GAAP assurance. Lower top-tier auditor use is also consistent with the cash constraints of resource DSE's (Lee et al., 2003), discussed above in Section 3.2. Therefore, we argue the difference in top-tier auditor use by resource DSE's is explained by firm characteristics, consistent with our hypothesis.

\section{Conclusion}

Large accounting scandals (such as Enron, Parmalat and HIH Insurance), as well as the more recent issues with the toxic legacy assets associated with the Global Financial Crisis, have encouraged the financial press to name and shame public companies with perceived corporate governance deficiencies. Despite academic research stressing the complexities surrounding the demand and supply of individual mechanisms within a corporate governance package, corporate governance scoring systems have become popular in the financial press. This paper aims to consider whether the governance choices made by resource DSE's are economically justifiable and reflect fundamental differences in the way industries function. In doing so, we provide a deeper level of analysis of the differences in corporate governance between resource and non-resource firms, as systematic differences are likely associated with underlying firm characteristics as opposed to exclusively non-compliance or mismanagement. We document substantial differences in firm characteristics. First, resource DSE's typically have a smaller organisational structure as illustrated by fewer management personnel and 
employees. ${ }^{16}$ Second, resource DSE's have less debt-based monitoring, consistent with debt capital being expensive for firms with high operating risk. Third, higher stock market participation for resource DSE's relative to non-resource firms, warrants deeper analysis controlling for the effects of the cyclical nature of the commodity market. Fourth, the lower analyst coverage of resource DSE's, potentially suggests a less developed information environment.

After controlling for firm characteristics, popular metrics, such as board size and top-tier auditor use are similar between the two sub-samples. However, resource DSE's exhibit a higher frequency of CEO-chair duality and a lower frequency of majority board independence. As suggested, this is consistent with the greater value of technical competence in the resource sector. Resource DSE's also have lower cash bonus usage for their CEO's compared to non-resource firms, but similar usage of equity compensation, consistent with cash constraints. Univariate results depict resource firms having lower ownership concentration but results are difficult to interpret.

Overall, we demonstrate that most differences in governance characteristics between resource DSE's and similar sized non-resource firms are a function of differences in underlying firm characteristics and are unlikely to be caused by management intentionally choosing poor governance or non-compliance. Furthermore, our evidence suggests that media criticisms of the resource sector are likely exaggerated and equally applicable to small firms more generally. If poor governance was endemic in the Australian resource industry, the reported strong share price performance of the resource sector sample in this study and more broadly could not be reconciled in an efficient capital market. In light of such evidence, we suggest

\footnotetext{
${ }^{16}$ Fewer employees is also consistent with the existence of cash constraints, and future research matching subsamples on the basis of number of employees may suggest that resource DSE's have 'better' corporate governance than non-resource firms.
} 
that consistent with Brickley \& Zimmerman (2010), governance scoring systems and 'boxticking' exercises may in fact be misleading. ${ }^{17}$ The media and regulators alike should consider more carefully the implications of fundamental differences in the economics underpinning governance choices in different industries. Our analysis is exploratory and we encourage future research that rigorously examines individual corporate governance mechanisms.

\footnotetext{
17 Although, the comparison of corporate governance scores can be meaningful if the underlying firm characteristics are identical. However, commentators have questioned whether it is possible for firm characteristics to ever be identical, whether corporate governance and firm characteristics can be exhaustively measured and efficient contracting would suggest that residual differences are transitory.
} 


\section{References}

Altman, E. 1968, 'Financial Ratios, Discriminant Analysis and the Prediction of Corporate Bankruptcy', Journal of Finance, 23, 4: 589-609.

Anderson, D., Francis J. and Stokes, D. 1993, 'Auditing, directorships and the demand for monitoring', Journal of Accounting and Public Policy, 12, 4: 353-375.

Anderson, R., Mansi, S. and Reeb, D. 2004, 'Board characteristics, accounting report integrity, and the cost of debt, Journal of Accounting and Economics, 37, 3: 315-342.

Armstrong C., Guay W. and Weber, J. 2010, 'The role of information and financial reporting in corporate governance and debt contracting', Journal of Accounting and Economics, 50, 2-3: 179-234.

Ball, R. and Brown, P. 1980, 'Risk and Return from Equity Investments in the Australian Mining Industry: January 1958 - February 1979’, Australian Journal of Management, 5, 1: 45-66.

Bhagat, S. and Black, B. 2002, 'The non-correlation between board independence and long-term firm performance', Journal of Corporation Law, 27, 2: 231-273.

Bhagat, S. and Bolton, B. 2008, 'Corporate governance and firm performance', Journal of Corporate Finance, 14, 3: 257-273.

Brickley, J., Coles, J. and Linck, J. 1999. 'What happens to CEOs after they retire? New evidence on career concerns, horizon problems, and CEO incentives', Journal of Financial Economics, 52, 3: 341-377.

Brickley, J. and Zimmerman, J. 2010, 'Corporate governance myths: Comments on Armstrong, Guay, and Weber', Journal of Accounting and Economics, 50, 2-3: $179-234$.

Brown, P., Lee, M. and Walter, T. 2009, 'Corporate Governance and the Long-Run Performance of Firms Issuing Seasoned Equity: An Australian Study', 22 ${ }^{\text {nd }}$ Australasian Finance and Banking Conference 2009. 
Brown, P., Beekes, W. and Verhoeven, P. 2011, 'Corporate governance, accounting and finance: A review', Accounting and Finance, 51, 1: 96-172.

Chen, C., Lin, J. and Yi, B. 2008, 'CEO duality and firm performance: an endogenous Issue', Corporate Ownership and Control, 6, 1: 58-65.

Coles, J., Daniel, N. and Naveen, L. 2008, 'Boards: Does one size fit all', Journal of Financial Economics, 87, 2: 329-356.

Conyon, M., Core, J. and Guay, W. 2011, 'Are US CEOs Paid More Than UK CEOs? Inferences From Risk-Adjusted Pay?', Review of Financial Studies, 24, 2: 402-438.

Dahya, J., Dimitrov, O. and McConnell, J. 2008, 'Dominant shareholders, corporate boards and corporate value: a cross-country analysis', Journal of Financial Economics, 87, 1: 73-100.

DeAngelo, L. 1981, 'Auditor size and audit quality', Journal of Accounting and Economics, 3, 3: 183-199.

Featherstone, T. 2010, 'A new gold rush', Company Director Magazine, September. Ferguson, A. and Crockett, A. 2003, 'Information Transfer and Press Coverage: The Case of the Gawler Craton Gold Boom', Pacific-Basin Finance Journal, 11, 1: 101120.

Ferguson A., Clinch, G. and Kean, S. 2011, 'Predicting failure of development mining projects', Australian Accounting Review, 21, 1: 44-53.

Ferguson, A. 2011. 'Determinants and usefulness of Non-GAAP voluntary disclosure in an unregulated financial statement void', UTS Working paper.

Glanville, B. 2007, 'Corporate governance being forgotten: report', ABC News, 30 November 2007, available at www.abc.net.au/news/stories/2007/11/30/2105730.htm last accessed 5 June 2011. 
Hermalin, B. and Weisbach, M. 1998, 'Endogenously chosen boards of directors and their monitoring of the CEO', American Economic Review, 88, 1: 96-118.

Huang, H., Wang, Q. and Zhang, X. 2009, 'The effect of CEO ownership and shareholder rights on cost of equity capital', Corporate Governance, 9, 3: 255-270.

Jensen, M. and Meckling, W. 1976, 'Theory of the Firm: Managerial Behaviour, Agency Costs and Ownership Structure', Journal of Financial Economics, 3, 4: 305-360.

Larcker, D., Richardson, S. and Tuna, I. 2007, 'Corporate Governance, Accounting Outcomes, and Organizational Performance', Accounting Review, 82, 4: 963-1008.

Lardaro, L. 1993, Applied Econometrics, New York, Harper Collins.

Lee, P., Stokes, D., Taylor, S. and Walter, T. 2003, 'The association between audit quality, accounting disclosures and firm-specific risk: evidence from initial public offerings', Journal of Accounting and Public Policy, 22, 5: 377-400.

Linden, P. and Matolcsy, Z. 2004, 'Corporate Governance Scoring Systems: What Do They Tell Us?', Australian Accounting Review, 14, 1: 9-16.

Matolcsy, Z. and Wright, A. 2007, 'Australian CEO compensation: The descriptive evidence', Australian Accounting Review, 17, 3: 47-59.

McConnell, J. and Servaes, H. 1990, ‘Additional Evidence on Equity Ownership and Corporate Value', Journal of Financial Economics, 27, 2: 595-612.

Morck, R., Shleifer, A. and Vishny, R. 1988, 'Management Ownership and Market Valuation', Journal of Financial Economics, 20, 1: 293-315.

Patro, S., Lehn, K. and Zhao, M. 2009, 'Determinants of the Size and Structure of Corporate Boards: 1935-2000', Financial Management, 38, 4: 747-780.

Shleifer, A. and Vishny, R. 1986, 'Large Shareholders and Corporate Control', Journal of Political Economy, 94, 3: 461-488. 
Tyler, J., Matolcsy, Z. and Wells, P. 2010, 'Was Corporate Governance Regulation Really the Answer?', UTS Working paper.

WHK Horwath. 2009, '2009 Corporate Governance Report'. 


\begin{tabular}{|c|c|c|}
\hline \multirow{2}{*}{\multicolumn{3}{|c|}{$\begin{array}{l}\text { Table 1 Data Definitions } \\
\text { Panel A - Corporate Governance Variables }\end{array}$}} \\
\hline & & \\
\hline \multirow[t]{4}{*}{ ASX Principles } & Board Size & Number of directors on the board \\
\hline & Board Independence & Percentage of self-designated independent directors on the board \\
\hline & Majority Independence & Frequency of boards with independence greater than $50 \%$ \\
\hline & Chair/CEO Duality & Frequency of boards with the CEO as the chair \\
\hline \multirow[t]{3}{*}{ CEO Compensation } & CEO Cash Pay ('000) & Total cash compensation for the CEO \\
\hline & CEO Equity Plan & Frequency of equity-based compensation plans \\
\hline & CEO Cash Bonus & Frequency of cash bonuses \\
\hline \multirow[t]{6}{*}{ Ownership Structure } & Substantial Shareholders & Number of substantial shareholders ( $5 \%$ or more) \\
\hline & Largest Shareholding & Holding of the largest shareholder \\
\hline & Top 20 Shareholdings & Percentage of firm stock held by the top 20 shareholders \\
\hline & CEO Shareholdings & Percentage of firm stock held by CEO \\
\hline & Board Shareholdings & Percentage of firm stock held by Board (excl. CEO) \\
\hline & KMP Shareholdings & Percentage of firm stock held by KMP (excl. executive directors) \\
\hline Audit & Top-tier & Frequency of top-tier audit firms \\
\hline \multicolumn{3}{|c|}{ Panel B - Firm Characteristics } \\
\hline \multirow[t]{3}{*}{ Employees } & \begin{tabular}{|l} 
Key Management \\
Personnel (KMP)
\end{tabular} & $\begin{array}{l}\text { Number of executives listed in the disclosure of the top } 5 \text { executive's } \\
\text { compensation }\end{array}$ \\
\hline & Employee Expense & $\begin{array}{l}\text { Total compensation paid to employees (excl. executive directors) } \\
\text { divided by total assets }\end{array}$ \\
\hline & CEO/Employee Expense & CEO cash pay divided by employee expenses \\
\hline \multirow[t]{6}{*}{ Financial Position } & Total Assets ('000) & Total assets \\
\hline & Market-to-Book & Market capitalisation divided by the book value of ordinary equity \\
\hline & Debt-to-Equity & Debt divided by market capitalisation (restricted to firms with debt) \\
\hline & New Debt Capital & Frequency of purchasing of new debt \\
\hline & Long-term Debt Capital & Frequency of long-term debt (new and old) \\
\hline & Current Ratio & Current assets divided by current liabilities \\
\hline \multirow[t]{7}{*}{ Financial Performance } & Return-on-Assets & Earnings before interest and tax divided by total assets \\
\hline & Return-on-Equity & Net Profit divided by the book value of ordinary equity \\
\hline & Dividends & Frequency of dividends \\
\hline & Negative Free Cash Flows & Frequency of negative free cash flows \\
\hline & Cash Burn & $\begin{array}{l}\text { Current assets minus current liabilities, divided by free cash flows } \\
\text { (restricted to firms with negative free cash flows) }\end{array}$ \\
\hline & Stock Return & Average monthly stock return \\
\hline & Return Volatility & Standard deviation of monthly stock return \\
\hline \multirow[t]{4}{*}{ Stock Market Activity } & Analyst Coverage & Frequency of public equity analyst coverage \\
\hline & Number of Analysts & Number of analysts (restricted to firms with analyst coverage) \\
\hline & Stock Turnover & Average monthly stock volume divided by the number of issued stock \\
\hline & Turnover Volatility & Standard deviation of monthly stock turnover \\
\hline
\end{tabular}




\begin{tabular}{|c|c|c|c|c|c|c|c|c|c|c|c|c|c|}
\hline \multirow{2}{*}{\multicolumn{2}{|c|}{$\frac{\text { Table } 2 \text { Descriptive Data }(\mathbf{2 0 0 9})}{\text { Panel A - Corporate Governance Variables }}$}} & \multicolumn{2}{|l|}{ Resource DSE's } & & & & \multicolumn{2}{|c|}{ Non-Resource Firms } & & & & Comparisons & \multirow[b]{2}{*}{$z$-stat } \\
\hline & & Mean & Std. Dev. & $\operatorname{Min}$ & Median & Max & \begin{tabular}{|l|} 
Mean \\
\end{tabular} & Std. Dev. & $\operatorname{Min}$ & Median & Max & $t$-stat & \\
\hline \multirow[t]{4}{*}{ ASX Principles } & Board Size & 4.3 & 1.6 & 3.0 & 4.0 & 10.0 & 4.6 & $\begin{array}{l}1.3 \\
\end{array}$ & 3.0 & 5.0 & 9.0 & $-2.057 * *$ & $-2.687 * * *$ \\
\hline & Board Independence & $43 \%$ & $25 \%$ & $0 \%$ & $38 \%$ & $100 \%$ & $45 \%$ & $24 \%$ & $0 \%$ & $50 \%$ & $100 \%$ & $\begin{array}{l}-0.739 \\
\end{array}$ & \begin{tabular}{|l|l|}
-0.661 \\
\end{tabular} \\
\hline & Majority Independence & $33 \%$ & & & & & $38 \%$ & & & & & & \\
\hline & Chair/CEO Duality & $19 \%$ & & & & & $8 \%$ & & & & & & \\
\hline \multirow[t]{3}{*}{ CEO Compensation } & CEO Cash Pay ('000) & \begin{tabular}{l|l}
513.40 & $\$$ \\
\end{tabular} & 813.11 & 21.80 & 262.66 & $5,345.00$ & $\begin{array}{l}571.43 \\
5\end{array}$ & 645.76 & 22.73 & 381.98 & $4,039.38$ & -0.829 & $-3.018 * * *$ \\
\hline & CEO Equity Plan & $49 \%$ & & & & & $49 \%$ & & & & & & \\
\hline & CEO Cash Bonus & $8 \%$ & & & & & $42 \%$ & & & & & & \\
\hline \multirow{6}{*}{ Ownership Structure } & Substantial Shareholders & 2.4 & 1.4 & 0.0 & 2.0 & 6.0 & 3.4 & 1.7 & 0.0 & 3.0 & 8.0 & $-4.312 * * *$ & $-4.052 * * *$ \\
\hline & Largest Shareholding & $17 \%$ & $17 \%$ & $0 \%$ & $13 \%$ & $82 \%$ & $25 \%$ & $19 \%$ & $4 \%$ & $18 \%$ & $99 \%$ & $-3.022 * * *$ & $-3.400 * * *$ \\
\hline & Top 20 Shareholdings & $58 \%$ & $17 \%$ & $11 \%$ & $60 \%$ & $98 \%$ & $69 \%$ & $16 \%$ & $25 \%$ & $70 \%$ & $100 \%$ & $-4.729 * * *$ & $-4.636 * * *$ \\
\hline & CEO Shareholdings & $5 \%$ & $9 \%$ & $0 \%$ & $3 \%$ & $62 \%$ & $9 \%$ & $15 \%$ & $0 \%$ & $2 \%$ & $88 \%$ & $-1.890 *$ & $\begin{array}{ll}0.401 & 0 \\
\end{array}$ \\
\hline & Board Shareholdings & $7 \%$ & $10 \%$ & $0 \%$ & $3 \%$ & $47 \%$ & $14 \%$ & $15 \%$ & $0 \%$ & $9 \%$ & $71 \%$ & \begin{tabular}{|l|l|}
$-3.603^{* * *}$ \\
\end{tabular} & $-2.893 * * *$ \\
\hline & KMP Shareholdings & $0 \%$ & $1 \%$ & $0 \%$ & $0 \%$ & $5 \%$ & $1 \%$ & $2 \%$ & $0 \%$ & $0 \%$ & $13 \%$ & $-3.205 * * *$ & $-3.352 * * *$ \\
\hline Audit & Top-tier & $28 \%$ & & & & & $46 \%$ & & & & & & \\
\hline \multicolumn{14}{|c|}{ Panel B - Firm Characteristics } \\
\hline \multirow[t]{3}{*}{ Employees } & KMP & 3.1 & 1.4 & 1.0 & 3.0 & 5.0 & 4.2 & 1.3 & 0.0 & 5.0 & 5.0 & $-5.796 * * *$ & $-5.725 * * *$ \\
\hline & Employee Expense & $10 \%$ & $21 \%$ & $0 \%$ & $4 \%$ & $149 \%$ & $38 \%$ & $59 \%$ & $0 \%$ & $24 \%$ & $522 \%$ & $-4.292 * * *$ & $-7.323 * * *$ \\
\hline & CEO/Employee Expense & $729 \%$ & $6090 \%$ & $1 \%$ & $52 \%$ & $60976 \%$ & $47 \%$ & $182 \%$ & $0 \%$ & $7 \%$ & $1479 \%$ & \begin{tabular}{|l|l|}
1.120 & \\
\end{tabular} & $8.491 * * *$ \\
\hline \multirow[t]{6}{*}{ Financial Position } & Total Assets ('000) & \begin{tabular}{ll|l}
62.07 & $\$$ \\
\end{tabular} & \begin{tabular}{l|l|}
196.51 \\
\end{tabular} & 0.27 & \begin{tabular}{l|l}
11.23 \\
\end{tabular} & 1,803.67 & $186.83 \$$ & $\begin{array}{l}569.38 \\
5\end{array}$ & \begin{tabular}{l|l}
1.02 \\
\end{tabular} & \begin{tabular}{l|l}
31.80 & 5
\end{tabular}$\quad r$ & $4,247.18$ & $-2.986 * * *$ & $-3.325 * * *$ \\
\hline & \begin{tabular}{|l|} 
Market-to-Book \\
\end{tabular} & 5.23 & 12.01 & -34.46 & 2.08 & 91.52 & 9.50 & 67.17 & -17.18 & 1.76 & 673.28 & \begin{tabular}{l|l}
-0.620 & \\
\end{tabular} & $1.747 *$ \\
\hline & Debt-to-Equity & 0.011 & 0.047 & 0.000 & 0.000 & 0.271 & 0.277 & 0.731 & \begin{tabular}{ll|l}
0.000 \\
\end{tabular} & 0.017 & 5.207 & $-3.560 * * *$ & $-2.453 * *$ \\
\hline & New Debt Capital & $17 \%$ & & & & & $54 \%$ & & & & & & \\
\hline & Long-term Debt Capital & $20 \%$ & & & & & $60 \%$ & & & & & & \\
\hline & \begin{tabular}{|l|} 
Current Ratio \\
\end{tabular} & 14.91 & 18.59 & 0.18 & 7.76 & 94.81 & 3.47 & 7.49 & 0.13 & 1.56 & 59.64 & $5.638 * * *$ & $6.956 * * *$ \\
\hline \multirow[t]{7}{*}{ Financial Performance } & Return-on-Assets & $-74 \%$ & $145 \%$ & $-732 \%$ & $-21 \%$ & $1 \%$ & $-20 \%$ & $61 \%$ & $-262 \%$ & $3 \%$ & $50 \%$ & $-3.459 * * *$ & $-6.465 * * *$ \\
\hline & Return-on-Equity & $-86 \%$ & $234 \%$ & $-1203 \%$ & $-24 \%$ & $720 \%$ & $-197 \%$ & $1783 \%$ & $-17732 \%$ & $0 \%$ & $1623 \%$ & \begin{tabular}{|c||c|}
0.613 & \\
\end{tabular} & $-4.2511^{* * *}$ \\
\hline & \begin{tabular}{|l|} 
Dividends \\
\end{tabular} & $0 \%$ & & & & & $27 \%$ & & & & & & \\
\hline & Negative Free Cash Flows & $93 \%$ & & & & & $57 \%$ & & & & & & \\
\hline & Cash Burn & 12.980 & 111.526 & 0.011 & 0.792 & 1076.770 & 2.331 & 6.917 & 0.000 & 0.592 & 51.090 & 0.955 & 0.761 \\
\hline & Stock Return & $7 \%$ & $6 \%$ & $-5 \%$ & $7 \%$ & $31 \%$ & $2 \%$ & $6 \%$ & $-18 \%$ & $1 \%$ & $21 \%$ & $5.483^{* * *}$ & $4.970^{* * *}$ \\
\hline & Return Volatility & $26 \%$ & $11 \%$ & $0 \%$ & $25 \%$ & $57 \%$ & $22 \%$ & $13 \%$ & \% $0 \%$ & $20 \%$ & $69 \%$ & $2.356 * *$ & $2.7344^{* * *}$ \\
\hline \multirow[t]{4}{*}{ Stock Market Activity } & Analyst Coverage & $16 \%$ & & & & & $38 \%$ & & & & & & \\
\hline & Number of Analysts & 2.625 & 2.553 & 1.000 & 2.000 & 11.000 & \begin{tabular}{ll|}
4.526 \\
\end{tabular} & 4.613 & 1.000 & 2.000 & 16.000 & $-3.305 * * *$ & -1.000 \\
\hline & Stock Turnover & 49.22 & 58.10 & 0.00 & 33.25 & 412.44 & 29.51 & \begin{tabular}{|l|}
44.27 \\
\end{tabular} & 0.00 & 10.43 & 286.50 & $2.877^{* * *}$ & $4.194 * * *$ \\
\hline & Turnover Volatility & 48.95 & 70.56 & 0.00 & 24.81 & 464.47 & 30.99 & 80.78 & 0.00 & 9.97 & 746.92 & $1.755 *$ & $3.920 * * *$ \\
\hline
\end{tabular}

Table 2 presents descriptive statistics and univariate analysis (parametric and non-parametric) for corporate governance and firm characteristic variables. Sample consists of 100 resource DSE's and 100 non-resource firms matched on market capitalisation. All variables defined in Table 1. $p$-values are matched and two-tailed. ${ }^{* * *} p<0.01,{ }^{* *} p<0.05,{ }^{*} p<0.10$. 
Table 3: Multivariate Analysis of Continuous Corporate Governance Variables

\begin{tabular}{|c|c|c|c|c|c|c|}
\hline & \multirow{2}{*}{\multicolumn{3}{|c|}{$\begin{array}{l}\text { Model I } \\
\text { Board Size }\end{array}$}} & \multirow{2}{*}{\multicolumn{3}{|c|}{$\begin{array}{c}\text { Model II } \\
\text { CEO Cash Pay (\$m) }\end{array}$}} \\
\hline & & & & & & \\
\hline & Coeff. & $p$-value & & Coeff. & $p$-value & \\
\hline Constant & 3.040 & 0.000 * & $* * *$ & 0.196 & 0.020 & $* *$ \\
\hline Resource & -0.124 & 0.587 & & -0.027 & 0.610 & \\
\hline KMP & 0.115 & $0.084 *$ & $*$ & 0.011 & 0.453 & \\
\hline Employee Expense & 0.355 & 0.360 & & 0.174 & 0.053 & $*$ \\
\hline Total Assets (\$m) & 0.007 & $0.000 *$ & $* * *$ & 0.001 & 0.000 & $* * *$ \\
\hline Market-to-Book & 0.025 & 0.150 & & 0.001 & 0.867 & \\
\hline Long-term Debt Capital & -0.174 & 0.361 & & -0.052 & 0.234 & \\
\hline Return-on-Assets & 0.252 & 0.113 & & 0.014 & 0.704 & \\
\hline Negative Free Cash Flow & 0.528 & $0.033 *$ & $* *$ & -0.018 & 0.751 & \\
\hline Cash Burn & 0.074 & 0.307 & & 0.011 & 0.500 & \\
\hline Stock Return & 0.719 & 0.636 & & 0.696 & 0.048 & $* *$ \\
\hline Return Volatility & 0.029 & 0.971 & & 0.110 & 0.544 & \\
\hline Analyst Coverage & 0.419 & $0.091 *$ & $*$ & 0.121 & 0.034 & $* *$ \\
\hline Stock Turnover & 0.006 & 0.265 & & 0.004 & 0.000 & $* * *$ \\
\hline Turnover Volatility & -0.007 & 0.166 & & -0.004 & 0.000 & $* * *$ \\
\hline Adjusted $R^{2}$ & 0.401 & & & 0.474 & & \\
\hline F-statistic & 10.502 & $0.000 *$ & $* * *$ & 13.794 & 0.000 & $* * *$ \\
\hline
\end{tabular}

Table 3 presents the results of OLS regressions for a selection of continuous corporate governance variables. Sample consists of 100 resource DSE's and 100 non-resource firms matched on market capitalisation. All variables defined in Table 1. $p$-values are matched and two-tailed. ${ }^{* * *} p<0.01,{ }^{* *} p<0.05,{ }^{*} p<0.10$. 
Table 4: Multivariate Analysis of Categorical Corporate Governance Variables

\begin{tabular}{|c|c|c|c|c|c|c|c|c|c|c|c|c|c|c|c|}
\hline & \multicolumn{3}{|c|}{ Model I } & \multicolumn{3}{|c|}{ Model II } & \multicolumn{3}{|c|}{ Model III } & \multicolumn{3}{|c|}{ Model IV } & \multicolumn{3}{|c|}{ Model V } \\
\hline & \multicolumn{3}{|c|}{ Majority Independence } & \multicolumn{3}{|c|}{ Chair/CEO Duality } & \multicolumn{3}{|c|}{ CEO Equity Plan } & \multicolumn{3}{|c|}{ CEO Cash Bonus } & \multicolumn{3}{|c|}{ Top-tier Auditor } \\
\hline & Coeff. & $p$-value & & Coeff. & $p$-value & & Coeff. & $p$-value & & Coeff. & $p$-value & & Coeff. & $p$-value & \\
\hline Constant & 0.837 & 0.265 & & -1.216 & 0.272 & & -2.144 & 0.006 & $* * *$ & -0.938 & 0.354 & & -1.288 & 0.137 & \\
\hline Resource & -0.886 & 0.067 & $*$ & 1.519 & 0.050 & $* *$ & 0.370 & 0.445 & & -1.152 & 0.071 & * & 0.320 & 0.565 & \\
\hline KMP & -0.187 & 0.178 & & -0.043 & 0.823 & & 0.286 & 0.037 & $* *$ & 0.176 & 0.379 & & -0.078 & 0.628 & \\
\hline Employee Expense & -1.201 & 0.155 & & -1.740 & 0.207 & & 1.655 & 0.040 & $* *$ & -0.331 & 0.740 & & 3.374 & 0.001 & $1 * * *$ \\
\hline Total Assets (\$m) & 0.000 & 0.993 & & 0.002 & 0.602 & & -0.003 & 0.251 & & -0.001 & 0.849 & & 0.010 & 0.006 & $5 * * *$ \\
\hline Market-to-Book & 0.033 & 0.362 & & 0.038 & 0.434 & & 0.027 & 0.463 & & 0.026 & 0.621 & & -0.012 & 0.770 & \\
\hline Long-term Debt Capital & 0.126 & 0.755 & & 1.471 & 0.015 & $* *$ & -0.189 & 0.633 & & 0.616 & 0.215 & & -0.189 & 0.685 & \\
\hline Return-on-Assets & -0.679 & 0.046 & $* *$ & -0.790 & 0.078 & $*$ & 0.214 & 0.519 & & 0.390 & 0.461 & & 0.639 & 0.149 & \\
\hline Negative Free Cash Flow & -0.599 & 0.242 & & -0.564 & 0.443 & & 0.886 & 0.092 & $*$ & -1.768 & 0.003 & $* * *$ & -0.662 & 0.270 & \\
\hline Cash Burn & -0.054 & 0.728 & & -0.235 & 0.390 & & 0.039 & 0.795 & & 0.277 & 0.161 & & 0.262 & 0.110 & \\
\hline Stock Return & 3.427 & 0.297 & & 4.210 & 0.399 & & 3.626 & 0.257 & & -3.500 & 0.426 & & 5.296 & 0.163 & \\
\hline Return Volatility & -4.245 & 0.018 & $* *$ & -6.175 & 0.027 & $* *$ & -1.930 & 0.237 & & -1.465 & 0.514 & & -1.800 & 0.358 & \\
\hline Analyst Coverage & 0.308 & 0.551 & & -1.272 & 0.193 & & 0.991 & 0.061 & $*$ & 1.636 & 0.006 & $* * *$ & 1.051 & 0.057 & $7 *$ \\
\hline Stock Turnover & 0.021 & 0.051 & * & -0.026 & 0.190 & & 0.027 & 0.022 & $* *$ & 0.007 & 0.590 & & -0.006 & 0.634 & \\
\hline Turnover Volatility & -0.002 & 0.825 & & 0.016 & 0.371 & & -0.027 & 0.018 & $* *$ & -0.003 & 0.811 & & 0.006 & 0.624 & \\
\hline Nagelkerke $R^{2}$ & 0.207 & & & 0.255 & & & 0.226 & & & 0.475 & & & 0.441 & & \\
\hline Chi square & 32.675 & 0.003 & $* * *$ & 30.069 & 0.007 & $* * *$ & 37.110 & 0.001 & $* * *$ & 77.373 & 0.000 & $* * *$ & 77.968 & 0.000 & $* * *$ \\
\hline
\end{tabular}

Table 4 presents the results of logistic regressions for a selection of categorical corporate governance variables. Sample consists of 100 resource DSE's and 100 non-resource firms matched on market capitalisation. All variables defined in Table $1 . p$-values are matched and two-tailed. $* * * p<0.01, * * p<0.05, * p<0.10$. 